\title{
Road infrastructure and intra-community trade in the Central African Economic and Monetary Community
}

\author{
Serge KAMGAING ${ }^{1}$, Jean Claude SAHA ${ }^{2}$ and Yves André ABESSOLO ${ }^{3}$ \\ ${ }^{1,3}$ Faculty of Economics and Management; University of Maroua, \\ ${ }^{2}$ Faculty of Economics and Management; University of Yaoundé II
}

\begin{abstract}
We examine the contribution of domestic and interstates road infrastructures to trade flow between member countries of the Central African Economic and Monetary Community (CEMAC). Theories of international economics as well as those of the new economic geography suggest a positive contribution of both road infrastructures to intraregional trade. A gravity model of international trade is estimated to evaluate this theoretical prediction in the CEMAC zone. Results confirm a positive contribution of interstate road infrastructure to intra-Community trade, but show no evidence of a positive contribution of domestic road infrastructure to intra- CEMAC trade.
\end{abstract}

Keywords: road infrastructure, intra-Community trade, gravity model

\section{Introduction}

The Central African Economic and Monetary Community (CEMAC) strikes as being one of the least integrated regional economic communities (RECs) around the world (Avom \& Fankem, 2014). CEMAC is a regional arrangement of six counties: Cameroon, Central African Republic, Chad, the Republic of Congo, Equatorial Guinea and Gabon. Statistics indicate that trade among member countries of this sub-region is limited to a few number of products and has rarely been above $2 \%$ of their total trade (UNCTAD, 2015). This performance is relatively low as compared to what can be observed in other RECs in Africa. As illustration, in 2017, the share of intra-Community exports as percentage of total trade of the Community was $20.9 \%$ in the South African Development Community (SADC) and $10.8 \%$ in the Economic Community of West African States (ECOWAS) (AfDB, 2019).

Petroleum accounts for more than 85 percent of CEMAC's exports. Therefore, economies in this zone are vulnerable to commodity cycles and falling in oil prices. Apart from Cameroon, the largest trading partner of the sub-region, CEMAC countries show less diversified economies. Cameroon exports manufactured good mainly to Chad and Central Africa Republic and Equatorial Guinea; and import in return oil and agricultural products (sugar and cattle) from Congo and Chad. Cameroon is also considered as the nourishing breast of the sub-region countries given exportations of food products (tomatoes, plantains, fruits and vegetables, beans, etc.) to the other countries.

Researches on the causes of this intra-community CEMAC trade have found that this trade is quantitatively and qualitatively poor because of the low production base and the small size of the economies, the infrastructure deficit, the limiting purchasing power of the population, the high level of corruption, etc. (Avom and Mignamissi, 2013; Gandjon Fankem, 2018; Koulakoumouna; 2012; Likibi, 2016). These research works have not sufficiently explored the role of transport infrastructure network. Indeed, in the CEMAC zone, low levels of intra-Community trade seems to be associated with the lack of adequate transport infrastructure network (AfDB, 2019). Data on infrastructures provision from the African Development Bank Group (AfDB) indicate that in 2006, road density in Central Africa was $3.5 \mathrm{~km}$ per 100 $\mathrm{km}^{2}$, one of the lowest in Africa. Indeed, in the Southern Africa, road density was above $13.5 \mathrm{~km}$ per 100 $\mathrm{km}^{2}$ in the same period and the average road density in Africa is $7.6 \mathrm{~km}$ per $100 \mathrm{~km}^{2}$. Additionally, a significant percentage of the CEMAC road network is unpaved: only $4.1 \%$ of total road network of this zone 
is asphalted, compared to $22 \%$ in West Africa region and $25 \%$ average in all African countries. Therefore, are road infrastructures in the CEMAC zone a determinant of intra-Community trade performance?

This study is an attempt to find a relationship between road infrastructures and trade between CEMAC countries. Specifically, we first evaluate the impact of domestic transport infrastructures on intra-community trade and, secondly, we estimate the impact of interstates transport infrastructures provision on intraCommunity trade in the CEMAC zone. Transport infrastructure is supposed to be the core component of a transport system. The good functioning of a transport service generally depends on the quality of its infrastructures. Good transport infrastructures facilitate the movement of people, goods, and services across countries, and play an important role in maintaining international economic, political and social relations (Koźlak, 2017). The CEMAC transport system consists mainly of roads, which accounts for $80 \%$ to $90 \%$ of freight movement and nearly $99 \%$ of passenger movement (AfDB, 2019). This means that shortages in road infrastructures in this sub-region can be a cause of low intra-community trade.

So our research questions in this work is: what is the impact of domestic road infrastructures, and what is the one of interstates road infrastructures on bilateral trade in CEMAC region? To answer these two questions, the paper is organized in three sections. In the first section (1), we review the literature on the effects of transport infrastructure on trade; in the second section (2) we discuss the theoretical model and present the empirical strategy; in the third section (3) we will present the results obtained from the econometric analysis; the paper ends with a conclusion.

\section{Literature Review}

\subsection{Theoretical literature review}

Theoretically, transport infrastructure played a key role in Adam Smith's vision of trade and economic development (Didier \& Prud'homme, 2007). Taking the example of fluvial navigation (canals), Adam Smith (1776) argued that transport infrastructure investments generate a reduction in transportation charges and an increase in travelling speed. The sectoral effect is an improvement in transportation conditions and a reduce transport costs which result into trade stimulation and economic growth. Such an analysis is in line with Bougheas et al. (1999) who assimilated transport infrastructure to "a cost-reducing technology". In Duranton et al. (2014) theoretical model for example, transport costs paid to travel from region $i$ to region $j$ is a negative function of the road capacity in each region and the roads connecting both regions.

Transport infrastructures investments generally result into direct and indirect effects, and these effects can be temporal or permanent (Annema et al., 2007). Direct effects of transport infrastructure generally include changes in exploitation costs, transport costs and time benefits for people and freight, which can improve the accessibility of regions. Indirect effects of transport infrastructure are viewed through the implication of transport costs reductions for the production and location decisions of people and firms, and through their effects on income, employment and changes in the environment. According to Rietveld (1994), the main target when investing in transport infrastructure is to improve accessibility and reduce transport costs.

Transport infrastructure endowment of a particular region/country can influence its ability to value specific comparative advantages, through transport costs reduction. When transport costs are extremely high, especially in the case of infrastructure shortages, countries or regions are constraint to produce locally all the goods and services that are necessary to satisfy their needs (Mayneris, 2018). Consequently, there is no specialisation at national or regional level. On the contrary, if transport costs are sufficiently low, countries or regions would have an incentive to specialise their production with respect to their comparative advantages, and trade would be beneficial to all participants (Rossi-Hansberg, 2005).

The new economic geography (NEG) theory provides an interesting framework to study the impact of transport costs and of transport infrastructure on the spatial distribution of economic activities. In this framework, good transport infrastructure permits a reduction in transport costs that generates a circular causation mechanism resulting in industrial agglomeration (Crozet, 2009; Krugman, 1991; Krugman \& Venables, 1995). In his pioneer contribution, Krugman (1991) used a setting characterized by increasing return to scale at the level of individual firm and transport costs to demonstrate the incentive for firms to 
concentrate their production near large markets. This practice is known as the Home Market Effect (HME), initially formalized by Krugman in 1980, and is considered as the main engine of NEG models (Crozet, 2009). The Home Market Effect suggest that larger regions should specialize in the production of increasing return to scale goods in order to reduce transport costs and take advantage in large quantity production. It also means that countries characterized by a larger demand for some products at home tend to have larger sales of the same products abroad (Costinot et al., 2019).

Transport costs are a major determinant of interregional trade in New Economic Geography analysis. According to Behrens (2005), when transport costs are high, there is no interregional trade regardless of the distribution of firms across regions; but if transport costs are low, interregional trade would take place regardless of the regional distribution of firms. In particular, when transport costs are small enough, activities may spread to less developed area, because dispersion forces become more powerful than agglomeration forces (Allen \& Arkolakis, 2014). The dispersion of activities across the space promote intra industry trade among regions.

\subsection{Empirical literature review}

Several empirical studies have found a positive influence of transport infrastructure on international trade. Di Stefano et al. (2021) based their analysis on the Belt and Road Initiative (BRI), a Chinese project to improve connectivity between Asia, Europe, and Africa. Up to March 2020, 138 countries around the world had signed a Memorandum of Understanding (MoU) with China to implement this project. First simulations showed that transport infrastructure projects related to the BRI would significantly reduce shipment times and trade costs, not only in the BRI countries but also in the rest of the world. De Soyres et al. (2020) concluded that the implementation of the BRI project would result in an increase of trade between 53 participating countries by 7.2 percent.

Empirical gravity equations are generally specified after considering the main determinants of trade costs, among which is road infrastructure (Akpan, 2014; Bougheas et al., 1999; Coulibaly \& Fontagné, 2006; Limão \& Venables, 2001). The gravity model of trade appeared as a particularly valued empirical technique in the field of international trade (Head \& Mayer, 2014; Inançli \& Mahamat Addi, 2019). In its simple form, the gravity model stipulates that bilateral trade between two countries is proportional to their respective size, measured by GDP, and inversely proportional to the geographic distance between them. The distance variable is usually presented as a proxy for unobservable trade costs (Novy, 2013).

Bougheas et al. (1999) and Limao and Venables (2001) are among the first to examine empirically the impact of road infrastructure on trade. Based on data of six European countries, Bougheas et al. (1999) concluded that a $10 \%$ increase in the stock of their transport infrastructure would lead to an increase in trade of around $1.6 \%$ to $4.6 \%$. Limao and venables (2001) investigated the relationship between transport infrastructure and trade, using an indicator of transport infrastructure computed by taking the average of the density of the road network, the paved road network, the rail network, and the number of telephone main lines per person. These authors obtained that infrastructure explain 40 percent of transport costs for coastal economies, and 60 percent for landlocked countries (36 percent for own infrastructure and 24 percent for transit infrastructure). They argued that poor transport infrastructure could explain why trade costs are relatively high in Sub-Sahara Africa and trade volumes substantially low.

In the same vein, Coulibaly and Fontagné (2006) analysed the influence of interstate roads quality on imports among member countries of the West African Economic and Monetary Union (WAEMU). The study concluded that if all the interstate roads were paved in WAEMU, member countries would trade 2.9 times more. In an analogue study, Akpan (2014) focused on the eleven coastal countries of the ECOWAS zone, located along the Lagos-Dakar Corridor, also called the Trans Coastal West African highway. The article found that raising the quality of road in the ECOWAS zone to that of South Africa would increase intra-Community trade by $5.3 \%$ relative to the 2012 level.

In the CEMAC zone, Avom and Mignamissi (2013) investigated the role of poor transport and production infrastructures on the productivity and competitiveness of this sub-region. They found that trade potential 
(the maximum level of trade that can be obtained if a country exploits all its trade capacity) of CEMAC member countries is still very important, specifically for intra-Community trade. Accordingly, Gbetnkom (2013) estimated that unexploited intra-Community trade potential is high enough for almost all the six CEMAC countries.

Koulakoumouna (2012) and Likibi (2016) also analysed the effects of transport infrastructure on economic activity in the CEMAC zone, and recommended that countries in this sub-region should invest to develop their transport infrastructure as a mean to foster intra-Community trade. This recommendation is in line with the result obtained by Gandjon Fankem (2018) who concluded that poor state of infrastructure reduced trade in Central Africa region by 15 percent. Infrastructure indicator used in the study combines rail density, road, paved road and telephone lines.

Our approach is based on Duranton, Morrow and Turner (2014)'s theoretical model that permits to estimate the a relationship between bilateral trade and road infrastructure within and between regions. The model suggests a two-step estimation strategy to assess the effects of roads infrastructure on bilateral trade. In the first step, the effect of roads linking regions on bilateral trade in a simple gravity equation of trade is estimated, considering importer and exporter countries' fixed effects. In the second step, the effect of roads within region on the propensity to export and to import of a region using is estimated, based on the results of the first step estimation. However, this strategy can generate endogenous problems due to the presence of estimated variables as explanatories variables and the absence of some theoretical variables that appears not to be measurable (Duranton et al., 2014). Moreover, if the number of observations is small, applying a twosteps approach would significantly reduce the degree of freedom. Therefore, we have chosen to apply an alternative estimation strategy in our empirical approach. This alternative estimation strategy is presented in the following section.

\section{Methodology}

\subsection{The Model}

Our model is based on the Duranton and al. (2014). We consider a sample of countries indexed by $i \in\{1, \ldots$ .,$I\}$, and assumes that each country produces a unique set of differentiated goods. A worker in a country supplies one unit of labour and uses his salary to purchase locally produced or imported goods. The number of workers/consumers is assumed to be the same in each country. Consumers maximize their utility represented in a CES-function with respect to their budget constraint, limited by their wages. Firms produce in constant rate of return conditions and their productivity is supposed to be the same in all sectors but can vary between countries. The model considers a continuum of sectors $k \in[0,1]$ to account for the fact that country employment in most sectors is small relative to total employment.

Transport costs are considered having three components: the cost of leaving a country $i, \tau_{x}^{k}\left(R_{i}\right)$; the cost of entering country $j, \tau_{m}\left(R_{j}\right)$ and the cost of moving from country $i$ to country $j \tau_{x m}\left(R_{i j}\right)$. Transport costs supported to leave exporter country $i$ depend negatively on the road provision of that country. Similarly, transport costs of entering country $j$ is a negative function of road provision in that country. Road infrastructure linking exporter and importer countries negatively influences the interstates component of the transport costs. Therefore, total transport costs to move from country $i$ to country $j$ can then be expressed as follow:

$$
\tau_{i j}^{k}=\tau^{k}\left(R_{i}, R_{i j}, R_{j}\right)=\tau_{x}^{k}\left(R_{i}\right) \tau_{x m}\left(R_{i j}\right) \tau_{m}\left(R_{j}\right)
$$

Given the above considerations, the equilibrium of the model leads to a trade equation that establishes a relationship between road and trade, in the following form:

$$
\ln X_{i j}=\delta_{i}^{X}+(1-\sigma) \ln \tau_{i j}+\delta_{j}^{M},
$$

Where $\ln X_{i j}$ stands for the logarithm of exportation value from country $i$ to country $j ; \delta_{i}^{X}$ is the propensity to export (or exporter fixed effect) and $\delta_{j}^{M}$ is the propensity to import (or importer fixed effect), $\ln \tau_{i j}$ is the 
logarithm of the chosen measure for interstates roads infrastructure between country $i$ country $j$. The propensity to export embodies the economic fundamentals of the exporter country that can affect its capacity to export: roads provision, population, unobserved productivity, export market access. Similarly, the propensity to import embodies the economic fundamentals of the importing countries that can affect its capacity to import: roads provision, population, productivity, import market access.

\subsection{Empirical strategy}

We base our empirical strategy on the estimation of a gravity model of trade integrating variables that can affect the propensity to export and the propensity to import. Unlike Duranton et al. (2014) or Duranton (2015), we directly estimate the equation of trade in a one-step procedure. Our empirical gravity equation of trade includes interstates roads and domestic roads provision indicators as explanatories or independent variables. This equation takes the following form:

$$
\begin{aligned}
\ln \left(\operatorname{Exp}_{i j}\right) & =\delta_{1} \ln \left(\text { PIB }_{i}\right)+\delta_{2} \ln \left(\text { PIB }_{j}\right)+\delta_{3} \ln \left(\text { Dist }_{i j}\right)+\delta_{4} \ln \left(\text { Pop }_{i}\right)+\delta_{5} \ln \left(\text { Pop }_{j}\right) \\
& +\delta_{6} \text { InfQual }_{i j}+\delta_{7} \ln \left(\text { InfRout }_{i}\right)+\delta_{8} \ln \left(\text { InfRout }_{j}\right)+\delta_{9} \text { Bord }_{i j}+\varepsilon_{i j}
\end{aligned}
$$

In which $X_{i j}$ is the value of exports from country $i$ to partner $j, G D P_{i}$ and $G D P_{j}$ are respectively the $G D P$ in country $i$ and in country $j$. Dist $t_{i j}$ is a measure of the bilateral distance between the two countries (their capital). InfQual ${ }_{i j}$ is a measure of quality of road infrastructure linking country $i$ and country $j$. InfRoad I $_{i}$

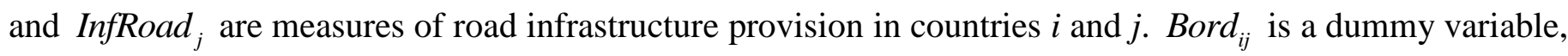
equal to 1 if both countries $i$ and $j$ share the same border, and 0 otherwise, $\varepsilon_{i j}$ is the error term. Symbol $\ln$ refers to the natural logarithm.

Parameters $\delta_{7}$ and $\delta_{8}$ are interpreted as measures of elasticities of exportations values from country $i$ to country $j$, respectively, to road infrastructure linking the two countries, road provision of the exporting country and road provision of the importing country. Parameter $\delta_{6}$ is interpreted as the effect on bilateral trade of a unit change in the index of the road quality linking both countries.

Given the log-linear form of the gravity equation, the ordinary least squares (OLS) method can result in biased and inconsistent results in the presence of numerous zero value trade that will be automatically dropped during estimation, as well as in the presence of heteroscedasticity or when the independant variable is not normal (Motta,2019). Santos Silva and Tenreyro (2006) suggested applying a different estimation procedure to estimate the gravity equation of trade: the Pseudo-Poisson Maximum Likelihood (PPML). These authors concluded, after their simulations, that this procedure is robust event in the presence of heteroscedasticity and zeros in trade data.

\subsection{Data}

This study uses data on the value of bilateral exports of the six CEMAC member countries $\left(X_{i j}\right)$, extracted from the United Nation database on trade (COMTRADE). Our source for the nominal GDP of these countries is the World Development Indicators databank of the World Bank. We extracted statistics on road distance between CEMAC capitals (Dist $t_{i j}$ ) from the "Centre d'Études Prospectives et d'Informations Internationales" (CEPII) database. Data on road infrastructure provision for the six CEMAC ( InfRoad $\left._{i}\right)$ are $^{2}$ withdrawn from the Subregional Office for Central Africa of the United Nations Economic Commission for Africa (ECA/SRO-CA). These data are available only in 2004 and 2010. The indicator on the quality of road infrastructure between two countries ( InfQual $_{i j}$ ) is computed by multiplying the African Infrastructure Development Index (AIDI) of the African Development Bank score of each country and taking the squared root.

A five-year mean for all data in values is computed and centred in each period (2004 and 2010) to reduce fluctuations in trade data and the number of observations having zero in trade value. Finally, our database 
contains six observations with zero in trade data in 2004 and two observations with zero in trade data in 2010.

\section{Results and discussion}

Table 1 below reports the results of equation (3) obtained after applying OLS method (dependent variable expressed in natural logarithm) and PPML method (dependent variable expressed in value) for each period. Estimated coefficients are statistically insignificant when applying OLS with robust standard deviation. Estimated coefficient obtained applying PPML method deviate less. The results of the PPML estimation are preferred for our interpretation and analysis. Importing and exporting countries fixed effects are added to capture the impact of other factors not introduced in the trade equation.

Table 1: Regression estimation results for equation (3)

\begin{tabular}{|c|c|c|c|c|}
\hline \multirow[t]{2}{*}{ Variables } & \multicolumn{2}{|c|}{2004} & \multicolumn{2}{|c|}{2010} \\
\hline & $(O L S)$ & $(P P M L)$ & $(O L S)$ & $(P P M L)$ \\
\hline $\ln (\mathrm{PIBi})$ & $\begin{array}{c}0,47 \\
(0,39)\end{array}$ & $\begin{array}{c}0,66 * * * \\
(0,15)\end{array}$ & $\begin{array}{c}1,12 \\
(0,68)\end{array}$ & $\begin{array}{c}0,83 * * * \\
(0,22)\end{array}$ \\
\hline $\ln (\mathrm{PIBj})$ & $\begin{array}{c}2,54 * * * \\
(0,53)\end{array}$ & $\begin{array}{c}1,65^{* * * *} \\
(0,27)\end{array}$ & $\begin{array}{c}1,91 * * * \\
(0,55)\end{array}$ & $\begin{array}{c}3,37 * * * \\
(0,62)\end{array}$ \\
\hline $\ln$ (Distij) & $\begin{array}{c}0,19 \\
(0,52)\end{array}$ & $\begin{array}{c}0,30 \\
(0,23)\end{array}$ & $\begin{array}{c}-0,96 \\
(1,24)\end{array}$ & $\begin{array}{l}-0,31 \\
(0,26)\end{array}$ \\
\hline $\ln$ (Popi) & $\begin{array}{l}0,71^{*} \\
(0,35)\end{array}$ & $\begin{array}{l}0,52^{* * *} \\
(0,22)\end{array}$ & $\begin{array}{l}1,29 * * \\
(0,48)\end{array}$ & $\begin{array}{c}1,04 * * * \\
(0,24)\end{array}$ \\
\hline $\ln ($ Popj) & $\begin{array}{l}-0,46 \\
(0,33)\end{array}$ & $\begin{array}{l}-0,54^{*} \\
(0,33)\end{array}$ & $\begin{array}{c}0,21 \\
(0,60)\end{array}$ & $\begin{array}{c}0,04 \\
(0,23)\end{array}$ \\
\hline InfraQualij & $\begin{array}{c}0,05 \\
(0,28)\end{array}$ & $\begin{array}{c}0,02 \\
(0,13)\end{array}$ & $\begin{array}{l}1,09 * * \\
(0,49)\end{array}$ & $\begin{array}{c}0,82 * * * \\
(0,11)\end{array}$ \\
\hline $\ln ($ InfraRouti) & $\begin{array}{l}-0,91 \\
(0,59)\end{array}$ & $\begin{array}{l}-0,29 \\
(0,44)\end{array}$ & $\begin{array}{c}-1,73 * * \\
(0,80)\end{array}$ & $\begin{array}{c}-1,61 * * * \\
(0,34)\end{array}$ \\
\hline $\ln ($ InfraRoutj) & $\begin{array}{l}-1,17 \\
(0,62)\end{array}$ & $\begin{array}{c}-1,20 * * * \\
(0,43)\end{array}$ & $\begin{array}{l}-\mathbf{- 0 , 1 2} \\
(0,94)\end{array}$ & $\begin{array}{c}-1,67 * * * * \\
(0,46)\end{array}$ \\
\hline Bordij & $\begin{array}{l}1,54 * * \\
(0,67)\end{array}$ & $\begin{array}{c}2,41 * * * \\
(0,62)\end{array}$ & $\begin{array}{c}0,72 \\
(1,32)\end{array}$ & $\begin{array}{c}0,34 \\
(0,57)\end{array}$ \\
\hline FEi & $\begin{array}{l}-0,15^{*} \\
(0,22)\end{array}$ & $\begin{array}{c}0,11 \\
(0,08)\end{array}$ & $\begin{array}{c}0,00 \\
(0,32)\end{array}$ & $\begin{array}{c}-0,02 \\
(0,16)\end{array}$ \\
\hline FMj & $\begin{array}{l}-0,47 \\
(0,30)\end{array}$ & $\begin{array}{c}-0,73 * * * \\
(0,25)\end{array}$ & $\begin{array}{l}-0,37 \\
(0,41)\end{array}$ & $\begin{array}{c}-0,69 * * * \\
(0,16)\end{array}$ \\
\hline $\mathrm{N}$ & 24 & 30 & 28 & 30 \\
\hline $\mathrm{F}$ & 9762,54 & - & 220,72 & - \\
\hline Ajusted-R ${ }^{2}$ & 0,98 & 0,86 & 0,97 & 0,72 \\
\hline
\end{tabular}

Standard deviation in brackets, ***p-value $<0.01$, **p-value $<0.05, * p$-value $<0.1$

The coefficient of determination applying the PPML estimator is $86 \%$ in 2004 and $56 \%$ in 2010, meaning that the model explains a significant share of the variability in intra-CEMAC trade for each period. The signs of coefficients are stable over the periods.

The results show a positive and significant contribution of interstate roads infrastructures on bilateral trade in the CEMAC zone, given the positive coefficient associated with the variable InfQual $_{i j}$ for the two periods. This positive effect is in line with the prediction of the theoretical model. A number of previous studies also conclude on the existence of a positive contribution of the quality of interstate roads on intracommunity trade in other regional economic communities in Africa (Akpan, 2014; Coulibaly \& Fontagné, 2006). 
A surprising result is the negative contribution to bilateral trade of domestic road infrastructure in the exporting country as well as in the importing country. Our theoretical model predicts instead a positive and small contribution of roads within-city on the propensity to export and import values (Duranton et al., 2014). The small size of our sample small and intrinsic characteristic of the economies in the CEMAC zone may explain such a result. Indeed, CEMAC member states produce almost the same products and import goods that increase their dependence on the rest of the world (Ngangoue, 2016).

The influence of each gravity variable is in line with the theory: GDP has a positive contribution to trade and distance a negative contribution. We can see from our results that the elasticity to trade of exporting country GDP is stronger than that of importing country GDP. Distance between countries has a negative impact on their bilateral trade. Moreover, sharing the same border may have a positive effect on trade in line with the theory.

The exporting country's population has a positive effect on intra-Community trade in the CEMAC zone, whereas the contribution of importing country population is negative. In fact, the size of a population can have a positive and a negative impact on trade (Filippini \& Molini, 2003; Jugurnath et al., 2007). On the one hand, a large population in a country means large labour supply, important domestic market that can lead to production diversification, and a reduction in its importation. On the other hand, a large population can reflect an important potential demand for domestic and imported products.

Our main contribution in this paper is to assess the effect of road infrastructure on intra-CEMAC trade. This paper prolongs studies that had identified road infrastructure as an impediment to trade or stress the need for CEMAC member countries to invest in the development of their transport infrastructures as a mean to improve their intra-Community trade (Gandjon Fankem, 2018; Koulakoumouna, 2012; Likibi, 2016).

It can be interesting in future research to include trade with big neighbouring countries of CEMAC zone such as Nigeria and Angola to capture their individual influence on intra-Community trade. It can also be interesting to adopt a sectoral approach in the analysis, for example by focusing specifically on agricultural sector. Such an approach requires sectorial data on trade not available in many countries due to the state of the production of statistic. Building a statistical information system that is able to generate up-to-date data on agricultural production and trade remains a great challenge in the CEMAC as confirm by the low statistical capacity indicators of the member countries.

\section{Conclusion}

Developing an efficient transport system aims to reduce transport costs and facilitate trade. In this paper, we have assessed the influence of member countries domestic and interstate roads on intra-Community trade in the CEMAC zone. Our results show a positive contribution of interstate roads $s$ to trade between member states of this sub-region, but do not confirm a positive contribution of domestic road infrastructure of CEMAC countries to intra-Community trade. Based on these results, we recommend the six countries of CEMAC to strengthen investment to improve their road network and to harmonize their national infrastructure development strategies.

\section{References}

1. AfDB. (2019). Central Africa Regional Integration Strategy Paper 2019-2025 (African Development Bank Group). African Development Bank Group

2. Akpan, U. (2014). Impact of regional road infrastructure improvement on intra-regional trade in ECOWAS. African Development Review, 26(S1), 64-76

3. Allen, T., \& Arkolakis, C. (2014). Trade and the Topography of the Spatial Economy. The Quarterly Journal of Economics, 129(3), 1085-1140

4. Annema, J. A., Koopmans, C., \& Van Wee, B. (2007). Evaluating transport infrastructure investments: The Dutch experience with a standardized approach. Transport Reviews, 27(2), 125150

5. Avom, D., \& Fankem, G. S. G. (2014). Qualité du cadre juridique, corruption et commerce international: Le cas de la CEMAC. Revue d'economie politique, Vol. 124(1), 101-128 
6. Avom, D., \& Mignamissi, D. (2013). Évaluation et analyse du potentiel commercial dans la Communauté économique et monétaire de l'Afrique centrale (CEMAC). L'Actualité Économique, 89(2), 115-145

7. Behrens, K. (2005). Choix de localisation et structure du commerce intra-branche. Revue economique, Vol. 56(4), 965-982

8. Bougheas, S., Demetriades, P. O., \& Morgenroth, E. L. (1999). Infrastructure, transport costs and trade. Journal of International Economics, 47(1), 169-189

9. Costinot, A., Donaldson, D., Kyle, M., \& Williams, H. (2019). The more we die, the more we sell? A simple test of the home-market effect. The Quarterly Journal of Economics, 134(2), 843-894

10. Coulibaly, S., \& Fontagné, L. (2006). South-South trade: Geography matters. Journal of African Economies, 15(2), 313-341

11. Crozet, M. (2009). Commerce et géographie : La mondialisation selon Paul Krugman. Revue d'economie politique, Vol. 119(4), 513-534

12. De Soyres, F., Mulabdic, A., \& Ruta, M. (2020). Common transport infrastructure: A quantitative model and estimates from the Belt and Road Initiative. Journal of Development Economics, 143, 102415

13. Di Stefano, C., Iapadre, P. L., \& Salvati, I. (2021). Trade and Infrastructure in the Belt and Road Initiative: A Gravity Analysis Based on Revealed Trade Preferences. Journal of Risk and Financial Management, 14(2), 52

14. Didier, M., \& Prud'homme, R. (2007). Infrastructures de transport, mobilité et croissance. La Documentation française

15. Duranton, G. (2015). Roads and trade in Colombia. Economics of Transportation, 4(1-2), 16-36

16. Duranton, G., Morrow, P. M., \& Turner, M. A. (2014). Roads and Trade: Evidence from the US. Review of Economic Studies, 81(2), 681-724

17. Filippini, C., \& Molini, V. (2003). The determinants of East Asian trade flows: A gravity equation approach. Journal of Asian Economics, 14(5), 695-711

18. Gandjon Fankem, G. S. (2018). FRONTIĖRES NATIONALES ET COMMERCE RÉGIONAL: QUELS ENSEIGNEMENTS POUR L'AFRIQUE CENTRALE? Actualité Économique-Revue d'analyse Économique, 94(2)

19. Gbetnkom, D. (2013). Intégration régionale et potentialité commerciale dans la CEMAC : Une évaluation par le modèle de gravité. Techniques Financieres et Developpement, $N^{\circ} 111(2), 89-103$

20. Head, K., \& Mayer, T. (2014). Gravity equations: Workhorse, toolkit, and cookbook. In Handbook of international economics (Vol. 4, pp. 131-195). Elsevier

21. Inançli, S., \& Mahamat Addi, H. (2019). Trade Creation and Trade Diversion Effects in the Economic Community of Central African States. African Development Review, 31(3), 307-317

22. Jugurnath, B., Stewart, M., \& Brooks, R. (2007). Asia/Pacific regional trade agreements: An empirical study. Journal of Asian Economics, 18(6), 974-987

23. Koulakoumouna, E. (2012). Transport routier et effectivité de l'intégration régionale: Enjeux et contraintes pour le développement durable au sein de la CEMAC. Humanisme et Entreprise, $n^{\circ}$ 309(4), 61-84

24. Koźlak, A. (2017). The role of the transport system in stimulating economic and social development. Transport Economics and Logistics, 72, 19-33

25. Krugman, P. (1991). Increasing returns and economic geography. Journal of Political Economy, 99(3), 483-499

26. Krugman, P., \& Venables, A. J. (1995). Globalization and the Inequality of Nations. The Quarterly Journal of Economics, 110(4), 857-880

27. Likibi, G. S. M. (2016). Effets de la Qualité Des Institutions Sur le Commerce Intra-Zone: Cas De La Cemac. International Journal of Business and Management Invention, Volume 5(Issue 11), 78-89

28. Limão, N., \& Venables, A. J. (2001). Infrastructure, Geographical Disadvantage, Transport Costs, and Trade. The World Bank Economic Review, 15(3), 451-479. https://doi.org/10.1093/wber/15.3.451

29. Mayneris, F. (2018). Effets des infrastructures de transport sur le niveau et la localisation des activités économiques: Une analyse bibliographique. Document de travail 
30. Motta, V. (2019). Estimating Poisson pseudo-maximum-likelihood rather than log-linear model of a log-transformed dependent variable. RAUSP Management Journal, 54, 508-518

31. Ngangoue, F. (2016). Planifier et organiser la diversification économique en Afrique centrale. Revue Congolaise de Gestion, Numéro 21-22(1), 45-87

32. Novy, D. (2013). Gravity redux: Measuring international trade costs with panel data. Economic Inquiry, 51(1), 101-121

33. Rietveld, P. (1994). Spatial economic impacts of transport infrastructure supply. Transportation Research Part A: Policy and Practice, 28(4), 329-341. https://doi.org/10.1016/0965-8564(94)900078

34. Rossi-Hansberg, E. (2005). A spatial theory of trade. American Economic Review, 95(5), 1464-1491

35. Silva, J. S., \& Tenreyro, S. (2006). The log of gravity. The Review of Economics and Statistics, $88(4), 641-658$

36. UNCTAD. (2015). United Nations Conference on Trade and Development Annual Report: 2014 (United Nations Conference on Trade and Development). UN 